\title{
Neoteric Approach of Fluoxetine Laden Orodispersible Film for Non-compliant Pediatric Patients of Selective Mutism and Obsessive- compulsive Disorder
}

\author{
Seçici Mutizm ve Obsesif Kompulsif Bozukluğu olan Uyumsuz Pediatrik \\ Hastalar için Fluoksetin Ladenin Ağızda Dağılan Filmi için Yeni Yaklaşım
}

\author{
(D) Haseeb Anwar DAD 1,2 , (D) Asra Shanzeh SHABBIR 3,4 , (D) Saman ALI2,4*, (D) Tariq MAHMOOD2 \\ 1Zhejiang University College of Pharmaceutical Sciences, Department of Pharmaceutics, Hangzhou, China \\ 2University of Central Punjab Faculty of Pharmacy, Department of Pharmaceutics, Lahore, Pakistan \\ 3 Punjab University College of Pharmacy, Department of Pharmaceutics, Lahore, Pakistan \\ 4 Lahore Medical and Dental College Lahore Pharmacy College, Department of Pharmaceutics, Lahore, Pakistan
}

\begin{abstract}
Objectives: The objective of this research was to fabricate, characterize, and optimize fluoxetine laden orodispersible film (ODF), in enhancing dosage forms options for the pediatric population suffering from incapacitating psychotic disorders of selective mutism and obsessive-compulsive disorder, which will be ultimately beneficial in enhancing compliance factor and the quality of pharmacotherapy.

Materials and Methods: Solvent casting technique was used to formulate the ODF formed by natural hydrophilic polymers matrix of hydroxypropyl methylcellulose E15 and pullulan. Propylene glycol as plasticizing agent imparted satisfactory tenacity and flexibility to ODFs. Fourier transform infrared spectroscopy studies were performed to investigate any potential compatibility, and the results revealed no potential interaction between fluoxetine and excipients. Developed ODFs were evaluated for physicochemical properties, content uniformity, in vitro disintegration time, and in vitro dissolution time studies.

Results: The experimental data suggested that different polymer concentrations had a complex effect on content uniformity, in vitro disintegration time, and cumulative percentage drug release from the ODFs. TF7 was the most optimized formulation with a disintegration time of 10.66 sec and $99.37 \%$ drug release within 3 min. Additionally, the most optimized fluoxetine ODF was submitted to a Universal Testing Machine for tensile strength and percentage elongation determination. It was also further evaluated by thermogravimetric analysis, scanning electron microscopy and X-ray diffraction.
\end{abstract}

Conclusion: Fluoxetine ODFs of good pharmaceutical quality can be prepared on a small scale. Therefore, the perspective of using fluoxetine ODFs for individualized pharmacotherapy to ameliorate the compliance issues in selective mutism and OCD pediatric patients can be considered.

Key words: Fluoxetine, HPMC E15, obsessive-compulsive disorder, orodispersible film, pullulan, selective mutism

\section{ÖZ}

Amaç: Bu araştırmanın amacı, seçici mutizm ve obsesif-kompulsif bozukluğu gibi inkapasite edici psikotik bozuklukları olan pediatrik popülasyon için sonuçta uyum faktörünü ve farmakoterapinin kalitesini artırmada yararlı olabilecek fluoksetin yüklü ağızda dağılan filmi (ODF) imal etmek, karakterize etmek ve optimize etmektir.

Gereç ve Yöntemler: Hidroksipropil metil selüloz E15 ve pulluhanın doğal hidrofilik polimer matrisi tarafından olușturulan ODF'yi formüle etmek için çözücü döküm tekniği kullanılmıştır. Plastikleştirici madde olarak propilen glikol, ODF'lere tatmin edici dayanıklılı ve esneklik kazandırmıştır. 
Olası uyumluluğu araştırmak için fourier dönüşümü kızılötesi spektroskopisi çalışmaları yapılmış ve sonuçlar fluoksetin ile eksipiyanlar arasında potansiyel bir etkileșim olmadığını ortaya koymuștur. Geliștirilen ODF'ler fizikokimyasal özellikler, içerik homojenliği, in vitro parçalanma süresi ve in vitro çözünme süresi çalışmaları için değerlendirilmiştir.

Bulgular: Deneysel veriler farklı polimer konsantrasyonlarının, içerik tekdüzeliği, in vitro parçalanma süresi ve ODF'lerden kümülatif ilaç salımı yüzdesi üzerinde karmașık bir etkiye sahip olduğunu göstermiștir. TF7, 10,66 saniyelik dağılma süresi ve 3 dakika içinde \%99,37 ilaç salımı ile en optimize edilmiş formülasyon olarak belirlenmiştir. Ek olarak, en optimize fluoksetin ODF, gerilme mukavemeti ve uzama yüzdesi belirlemesi için bir Evrensel Test Makinesi'ne gönderilmiştir. Ayrıca termogravimetrik analiz, taramalı elektron mikroskobu ve X-ışını kırınımı ile de değerlendirilmiştir. Sonuç: İyi farmasötik kalitede fluoksetin ODF'leri küçük ölçekte hazırlanabilir. Bu nedenle, seçici mutizm ve OKB pediatrik hastalarda uyum sorunlarını iyileștirmek için bireyselleștirilmiş farmakoterapi için fluoksetin ODF'lerin kullanılması perspektifi düşünülebilir.

Anahtar kelimeler: Fluoksetin, HPMC E15, obsesif-kompulsif bozukluk, ağızda dağılan film, pulluhan, seçici mutizm

\section{INTRODUCTION}

The pediatric population comprises of heterogeneous age bracket as it encompasses the entire population from neonate to adolescence. For decades, complications faced by the pediatric population during the administration of oral dosage forms are not taken into grave account. About $90 \%$ of total marketed pediatric medicinal products are in liquid dosage forms. However, liquid dosage forms are replete with complications of erroneous dosing, instability, augmented contamination probability, and the requirement of a dedicated utensil for administration. ${ }^{2,3}$ Pediatric patients with disabilities, mentally challenged states, and psychotic disorders experience many hindrances in the oral administration of the drugs. ${ }^{4}$

Focusing on psychiatric disorders, selective mutism, and obsessive-compulsive disorder (OCD), which are anxiety disorders according to the Diagnostic and Statistical Manual of Mental Disorders-IV, inflict pediatric population and sometimes exist concurrently. ${ }^{5-7}$ Selective mutism, a complex incapacitating anxiety disorder with onset between two to five years of age, is typically delineated by perpetual failure to develop verbal communication in distinct social settings where verbal communication is required (e.g., school); however, such children can converse well in a domestic backdrop. 8,9 Similarly, OCD lands up the afflicted children in vitiated social and academic performance..$^{10,11}$

Selective serotonin reuptake inhibitors, an anti-depressant class of drugs, have been recommended to treat selective mutism and OCD due to their significant efficacy. ${ }^{12-14}$ Studies have reported the well-tolerated and effective treatment of OCD and selective mutism with fluoxetine, which diminishes the panic attacks and social phobias in a pediatric population. ${ }^{15-17}$ It is a well-reported fact that the pediatric population experiences dysphagia while intake solid dosage forms. ${ }^{18}$ One of the major factors, among others, might be the smaller dimensions of the children's pharynx and the developing oropharyngeal musculature. ${ }^{19}$

Therefore, this study aimed to fabricate the fluoxetine laden oral dispersible films to tackle the challenges. Orodispersible film (ODF) technology comprises a thin postage stamp-sized pliable strip manufactured of hydrophilic film-forming polymers and excipients, releasing active drugs within seconds on contact with saliva in the buccal cavity. Needless to mention that excipients incorporated in ODF, such as plasticizer, film stabilizer, saliva stimulating agent, taste masking agent, flavor, and super-disintegrant, must be Generally Regarded as Safe, i.e., GRAS listed according to Food and Drug Administration. ${ }^{20-22}$ In addition, one of the most salient and crucial components for the formation of ODF is the utilization of polymers. The optimal polymer utilization is vital to impart the required critical characteristics to ODF, for instance, solubility, hydrophilicity, pliability, and a pleasant mouthfeel. Recently, ODF technology has garnered massive attention for the delivery of active drugs, prone to deterioration and GIT due to enzymes and $\mathrm{pH}$ variation. Additionally, ODF offers substantial benefits like widened surface area, which shortens the disintegration and dissolution time. ${ }^{20}$ It ascertains the better accurate and precise dose per film compared to other dosage forms like syrup and drop. It is equipped with an oral absorbance feature, which leads to accelerated and enhanced bioavailability while offering less frequent dose schedule. Consequently, it led to enhanced clinical outcomes with minimized side effects. ${ }^{23}$ On top of that, ODFs are more palatable than other dosage forms, which enhance patient compliance. Moreover, its pliable nature is less frangible than an orally disintegrating tablet (ODT). ${ }^{24}$ It requires no water and no need for swallowing the whole film as it disintegrates in saliva. Further, it takes precedence over ODT among patients with fear of choking the tablets, making ODFs ideal for dysphagic patients. ${ }^{23}$ While ODFs represent phenomenal advantages, a major obstacle to their widespread application is the limited drug loading capability of ODFs, which only permits the incorporation of low-dose high potency drugs into ODFs. ${ }^{25}$

The objective of the current research was to formulate, optimize, and characterize the ODFs to attain faster disintegration leading to faster dissolution and brisk drug absorbance. In addition, our work aims to widen the dosage forms options for pediatric patients with selective mutism and OCD and enhance patient compliance to achieve better therapeutic outcomes. Furthermore, the influence of formulation parameters like (polymer, plasticizer) concerning their concentrations on ODF's evaluation was also investigated. 


\section{MATERIALS AND METHODS}

\section{Materials}

Fluoxetine was used as an active pharmaceutical ingredient (API) and was generously given by Wilshire Labs (Pvt) Ltd. Lahore, Pakistan. Pullulan, a film-forming polymer, was purchased from Sigma Aldrich. Hydroxypropyl methylcellulose (HPMC) low viscosity E15, a film-forming polymer, and polyvinylpyrrolidone (PVP) (crospovidone), a superdisintegrant, were purchased from Moringa Pharmaceutical Pvt. Ltd., Lahore, Pakistan. Propylene glycol (PG), an excellent plasticizer, was obtained from Sigma Aldrich. Citric acid used as a saliva stimulating agent and fructose as a sweetening agent were obtained from CCL Pharmaceutical Pvt. Ltd., Lahore, Pakistan. Phosphate-Buffer Saline pH 6.8 was purchased from the Pharmaceutical research Lab of the University of Central Punjab, Lahore, Pakistan. All the chemicals were of analytical grade.

\section{Methods}

The solvent casting evaporation method reported in previous literature was adapted with slight modification. ${ }^{26}$ The procedure involved solubilization of required quantity of film-forming polymers HPMC E15 and pullulan into distilled water. Then, plasticizer PG was solubilized into the hydropolymeric solution and stirred for $30 \mathrm{~min}$. Required quantities of fluoxetine, crospovidone (super-disintegrant), citric acid, and fructose were solubilized with distilled water in a separate beaker and mixed by stirring for $30 \mathrm{~min}$. The plasticizer and polymeric solution were poured into drug-excipients solution, and the final volume of the formulation was adjusted to $15 \mathrm{~mL}$. The final solution was homogenized at $1000 \mathrm{rpm}$ for $60 \mathrm{~min}$ by a highspeed homogenizer. The homogenized solution was kept aside for $1 \mathrm{~h}$ to remove all entrapped air bubbles. Next, the homogenized and almost air bubble-free solution was cast in petri dishes and placed in a hot air oven at $45^{\circ} \mathrm{C}$ for $24 \mathrm{~h}$. Subsequently, the dried film was meticulously peeled off, carved into $2 \mathrm{~cm} \times 2 \mathrm{~cm}$ ODFs, wrapped in aluminum foil, and stored in a desiccator until further use. Trials design and composition are shown in Table 1.

\section{Preformulation studies}

Fourier transform infrared spectroscopy (FTIR)

FTIR was employed to determine the compatibility between fluoxetine and excipients. The FTIR of fluoxetine and each excipient was performed independently. API and all excipients were in a 1:1 blended ratio. Each chemical was individually admixed with $\mathrm{KBr}$ and then scanned over the frequency range of 400 to $4000 \mathrm{~cm}^{-1} .27$

\section{Post-formulation studies}

\section{Physical appearance}

The physical appearance of all batches of ODFs was visually investigated considering multiple factors: Aesthetic appearance, color, ODF surface texture and its symmetry, peel ability of ODF from mold (degree of ease in removing ODF from the mold without cracks and punctures in its surface), stickiness, and its flexibility.

Table 1. Experimental trials design and composition

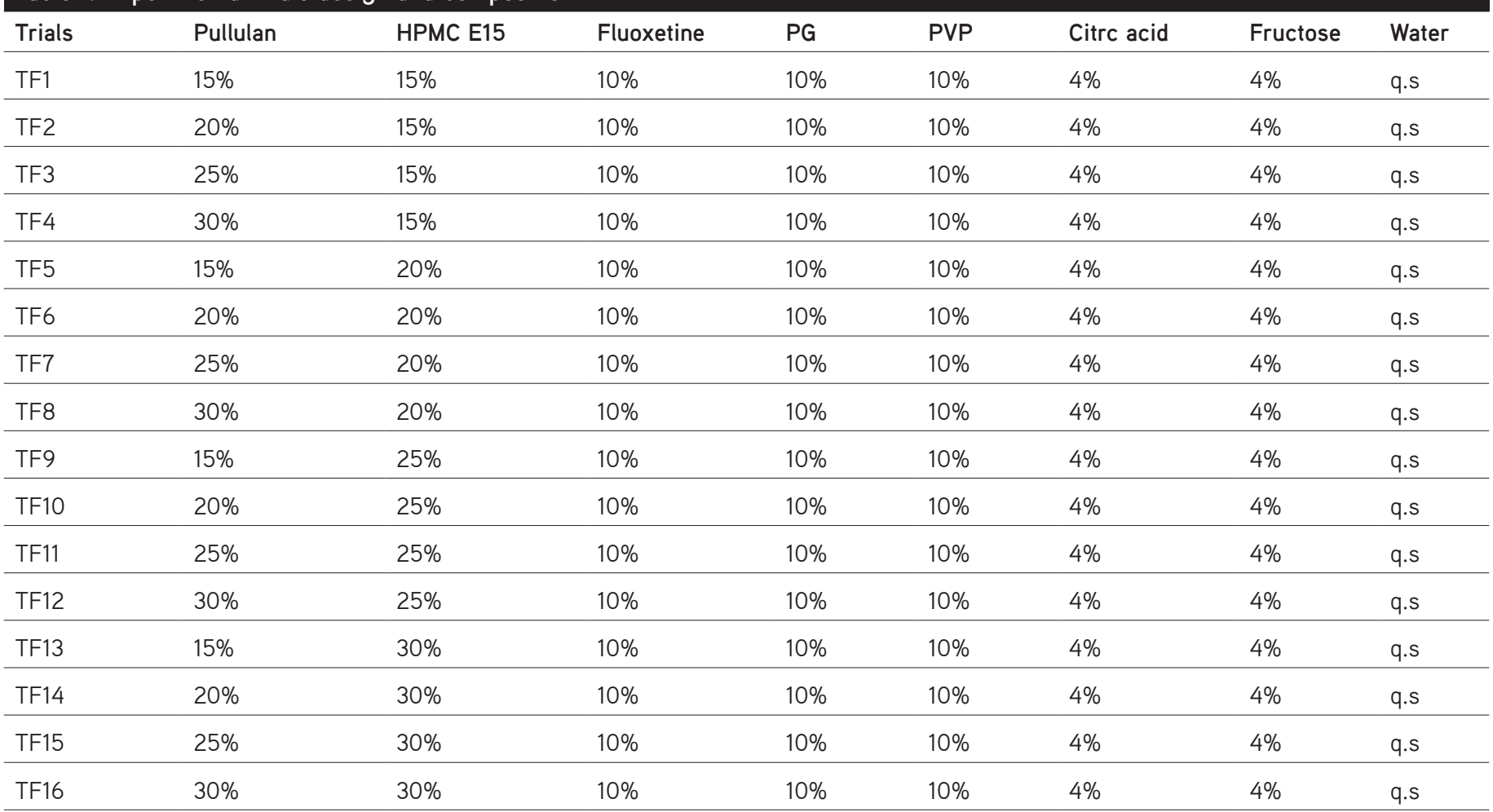

All quantities are expressed in \% w/v. HPMC: Hydroxypropyl methylcellulose, PG: Propylene glycol, PVP: Polyvinylpyrrolidone, q.s: Quanum satis 


\section{Mechanical characteristics}

\section{Weight variation}

Five oral strips from each batch were carved into $4 \mathrm{~cm}^{2}$ and weighed individually using an electronic weighing balance. The average weight of weighed ODFs was calculated and subtracted from individual strip weight. Less variation of resultant value suggests the efficiency of the method employed and uniform distribution of $\mathrm{API}$ and inactive ingredients across the surface of ODF. ${ }^{28}$

\section{Thickness}

Thickness determination of ODF holds great importance in revealing the drug's even distribution and appropriate thickness, which facilitates ODF's adhesion capability to the tongue. Consistency in thickness of the film validates the accurate dose embodied in the ODF. ${ }^{28}$ ODF thickness was measured using calibrated micrometer screw gauge at all the four corners and center points of individual ODF. Mean and standard deviation (SD) were calculated.

\section{Folding fortitude}

Folding fortitude manifests the pliability, tenacity, and resilience of ODF. It depicts the capability of ODF to withstand the folding on one plane without rupturing and cracking. ${ }^{29}$ This test was performed by repeatedly folding three ODF of each batch at a single plane until it cracked, and the value was expressed as folding endurance value.

\section{Drug content uniformity}

Drug content uniformity of fabricated ODFs was determined according to El-Setouhy and Abd El-Malak ${ }^{30}$ with modifications. ODF was cut into $4 \mathrm{~cm}^{2}$ and put into a beaker with $50 \mathrm{~mL}$ of phosphate buffer ( $\mathrm{pH} \mathrm{6.8)} \mathrm{and} \mathrm{stirred} \mathrm{for} 1 \mathrm{~h}$. Then, the solution was filtered using a syringe filter of $0.45 \mu \mathrm{m}$ pore size. Absorbance was read at $\lambda$ max of $263 \mathrm{~nm}$ using a ultraviolet (UV) spectrophotometer.

\section{Disintegration test}

Currently, there is no method for disintegration test specified in pharmacopeias officially. Among multiple reasons, the major and most demanding solution is a high volume of disintegration medium used in conventional dosage forms. Because high media volume does not simulate the biological and physiological condition of a buccal cavity due to limited saliva volume retaining capacity. In this consideration, several disintegration test techniques have been reported in the literature. ${ }^{31}$ By considering the popularity and feasibility, the petri dish method was chosen in which phosphate buffer of $\mathrm{pH} 6.8$ was used as a solvent medium for the in vitro disintegration test. ${ }^{32}$ ODF was cut into $4 \mathrm{~cm}^{2}$ and placed in a petri dish, and previously heated $2.5 \mathrm{~mL}$ of phosphate buffer $(\mathrm{pH}: 6.8)$ at $37^{\circ} \mathrm{C}$ was poured in the petri dish and whirled every $10 \mathrm{sec}$. The time (seconds) when ODF started to disintegrate and the fragment, was noted as in vitro disintegration time. ${ }^{33,34}$ Disintegration time for three ODFs of the same batch was determined, and the average was calculated.

\section{In vitro dissolution test}

There is no appropriate dissolution method for ODF mentioned in any of the pharmacopeias. Various published methods in previous research of ODF were taken into consideration due to the lack of any authentic official method prescribed and adapted. ${ }^{35,36}$ Hence, in vitro drug release was determined using USP paddle apparatus type II with $500 \mathrm{~mL}$ phosphate buffer $(\mathrm{pH}$ 6.8) and temperature set at $37 \pm 0.5^{\circ} \mathrm{C}$ at $50 \mathrm{rpm}$. ODF of $4 \mathrm{~cm}^{2}$ was cut and placed into the dissolution media. An aliquot of 5 $\mathrm{mL}$ was taken at $0 \mathrm{~min}, 0.5 \mathrm{~min}, 1 \mathrm{~min}, 1.5 \mathrm{~min}, 2 \mathrm{~min}, 2.5 \mathrm{~min}, 3$ $\mathrm{min}, 5 \mathrm{~min}, 7 \mathrm{~min}, 9 \mathrm{~min}$, and $11 \mathrm{~min}$, and immediately replaced with fresh media. Then, the sample was filtered through a filter syringe of $0.45 \mu \mathrm{m}$. The absorbance was read at $263 \mathrm{~nm}$ by UV visible spectrophotometer.

\section{Scanning electron microscopy (SEM)}

Surface morphology and framework of optimized formulation were scanned and examined by SEM. ODF was cut into $2 \mathrm{~cm} \times 2$ $\mathrm{cm}$, and its surface morphology was scanned with SEM (model JSM5910JEOL, Japan) at voltage acceleration of $10 \mathrm{kV}$ with a resolving power of max $2.3 \mathrm{~nm}$.

\section{Tensile strength, percent elongation, and Young's modulus}

Mechanical properties of tensile strength, percent elongation, and Young's modulus were evaluated using Universal Testing Machine (UTM) (100-500KN, Testometric Inc. UK). ${ }^{37}$ The optimized formulation of $30 \mathrm{~mm} \times 16 \mathrm{~mm}$ was placed between two clamps, situated at a distance of $2 \mathrm{~cm}$. One clamp was immotile while another clamp moved in the opposite direction at the speed of $1.00 \mathrm{~mm} / \mathrm{min} .{ }^{27}$ At the point of rupturing and cracking, force and elongation values were recorded. Tensile strength, percent elongation, and Young's modulus were computed by equations below: $: 37,38$

$$
\begin{gathered}
\text { Tensile Strength }\left(\mathrm{N} / \mathrm{mm}^{2}\right)=\frac{\text { Force at rupture }(\mathrm{N})}{\text { Thickness } X \text { width }\left(\mathrm{mm}^{2}\right)} \times 100 \\
\% \text { Elongation at break }=\frac{\text { Increase in length }}{\text { Initial lenath }} \times 100 \\
\text { Young's modulus }\left(\mathrm{N} / \mathrm{mm}^{2}\right)=\frac{\text { Force at corresponding strain }(\mathrm{N})}{\text { Cross sectional area }\left(\mathrm{mm}^{2}\right)} \times \frac{1}{\text { Corresponding strain }}
\end{gathered}
$$

\section{$X$-ray diffractometry}

The crystallinity of fluoxetine was estimated using X-ray diffractometry. X-ray diffraction (XRD) of optimized formulation, placebo formulation, and pure drug (fluoxetine) was performed. Drug powder and formulations were scanned in two thetas $(\theta)$ in a range from $19^{\circ}$ to $70^{\circ}$ with a tube voltage of $30 \mathrm{kV}$ and current of $10 \mathrm{~mA}$ and the usage of monochromatic copper radiation Cu Ka (k: $2 \AA$ ) with a nickel filter.

\section{Thermogravimetric analysis (TGA)}

TGA helps the researcher to construe the effect of temperature rise on the mass of the sample tested. The sample was subjected to heating, and consequent mass variation was detected by a sensitive balance in a controlled environment. Mass variation occurs due to multiple factors such as sample chemical atrophy and physical processes like drying, vaporization, and 
sublimation. The TGA was performed for the thermal analysis of optimized ODF and pure drug (fluoxetine) by gradually increasing temperature from $25^{\circ} \mathrm{C}$ up to $300^{\circ} \mathrm{C}$ at the rate of $10^{\circ} \mathrm{C}$ per minute while continuous exposure to heating by constant nitrogen flow $(20 \mathrm{~mL} / \mathrm{min})$.

\section{Statistical analysis}

All calculations were performed using Microsoft Excel ${ }^{\circledR}$ (Microsoft Office 2019, USA). All calculations are expressed as mean \pm SD except dissolution studies, which were expressed as mean of the percentage of the drug release.

\section{RESULTS AND DISCUSSION}

The FTIR spectrums of fluoxetine and blended fluoxetine with polymers and other excipients was observed, and no interaction was detected (not shown).

\section{Physical appearance}

Visual inspection revealed that trial formulations with polymer concentration cumulatively up to $40 \%$ were considered as failed batches. The trial number of TF1, TF2, and TF3 were unable to be detached from the petri dish. These trial formulations displayed significant adhesiveness presumably because of the low percentage of polymer and higher PVP concentration (Table 2). This pronounced adhesiveness can be attributed to the hydrophilic and hygroscopic nature of PVP, which ultimately imparts tackiness that could also be seen in TF5 and TF13. ${ }^{39}$ ODF batches with relatively higher pullulan content than HPMC rendered stickiness/tackiness and translucency. ODF batches with low pullulan and HPMC content were semitransparent as the polymer content accumulated, it imparted the translucency to the formulation. ODF batches with lower content of polymer exhibited wrinkles and curves in ODF

\section{Table 2. Physical appearance of trial formulations}

\begin{tabular}{|c|c|c|c|c|c|c|}
\hline Trial no. & Visibility & Surface texture & Wrinkles around edges & $\begin{array}{l}\text { Flexibility \& } \\
\text { brittleness }\end{array}$ & Tackiness & Peelability \\
\hline TF1 & Semitransparent & Coarse \& punctured & - & - & Extremely tacky & $0++$ \\
\hline TF2 & Semitransparent & $\begin{array}{l}\text { Bubbly, smooth, fragile, } \\
\text { punctured }\end{array}$ & Wrinkled and bent edges & Brittle & Extremely tacky & $0++$ \\
\hline TF3 & Translucent & $\begin{array}{l}\text { smooth, bubbly, thin } \\
\text { fragile,punctured }\end{array}$ & Slightly wrinkled edges & Brittle & Extremely tacky & $0+$ \\
\hline TF4 & Translucent & Smooth, intact surface & Wrinkleless straightened edges & Flexible & Non-tacky & $1+$ \\
\hline TF5 & Translucent & $\begin{array}{l}\text { Smooth, bubbly, and intact } \\
\text { surface }\end{array}$ & $\begin{array}{l}\text { Inconspicuous wrinkles } \\
\text { around edge }\end{array}$ & Flexible & Tacky & $1+$ \\
\hline TF6 & Translucent & Coarse and intact surface & Wrinkleless straightened edges & Flexible & Non-tacky & $1+$ \\
\hline TF7 & Translucent & $\begin{array}{l}\text { Extremely smooth and } \\
\text { intact }\end{array}$ & Wrinkleless straightened edges & Flexible & Non-tacky & $1++$ \\
\hline TF8 & Translucent & Smooth and intact & Wrinkleless straightened edges & Flexible & Slightly tacky & $1+$ \\
\hline TF9 & Translucent & Punctured surface & Wrinkleless straightened edges & Flexible & Slightly tacky & $0+$ \\
\hline TF10 & Translucent & Smooth bubbly and intact & Wrinkleless straightened edges & Flexible & Non-tacky & $1+$ \\
\hline TF11 & Translucent & Very smooth and intact & Wrinkleless straightened edges & Flexible & Non-tacky & $1++$ \\
\hline TF12 & Translucent & Very smooth and intact & Wrinkleless straightened edges & Flexible & Non-tacky & $1++$ \\
\hline TF13 & Translucent & $\begin{array}{l}\text { Extremely bubby, coarse, } \\
\text { and intact }\end{array}$ & Wrinkleless straightened edges & Flexible & Tacky & $0+$ \\
\hline TF14 & Translucent & Smooth and intact & Wrinkleless straightened edges & Flexible & Non-tacky & $1++$ \\
\hline TF15 & Translucent & $\begin{array}{l}\text { Slightly coarse thick and } \\
\text { intact }\end{array}$ & Wrinkleless straightened edges & $\begin{array}{l}\text { Partial } \\
\text { brittleness }\end{array}$ & Slightly tacky & $0+$ \\
\hline TF16 & Translucent & Coarse, thick, and intact & Wrinkleless straightened edges & Brittle & Slightly tacky & $0+$ \\
\hline
\end{tabular}

$1+$ : Good, $1++$ : Very good, 0 +: Poor, 0 ++: Very poor 
batches. Formulation trials TF5, TF7, TF11, TF12, and TF14 exhibited the exceptional characteristics of having a smooth and intact surface with minimum or no wrinkled edges and phenomenal detachability from petri dish mold. Almost similar physical appearance parameter outcomes were observed in the films of levocetirizine, in which ODF formed with low viscous polymer grades and the ODF with low polymer percentage content were difficult to be peeled from mold. Hence, it can be established that ODFs with low polymer content lacks detachability. Moreover, in levocetirizine ODFs, films with higher pullulan content were translucent in appearance. ${ }^{40}$

\section{Weight variation and thickness}

Weight variation and thickness tests were performed on five ODFs of all retrieved batches. TF1, TF2, TF3, and TF9 batches were unable to be detached and retrieved from mold. Therefore, these batches were not included in both tests. All ODF batches qualified for the \% weight variation according to USP pharmacopeial limit of $\pm 10 \%$ for dosage form with $130 \mathrm{mg}$ or less weight. Weight variation was within the range of 72.67 $\mathrm{mg} \pm 0.12-102.42 \mathrm{mg} \pm 1.41$ (Table 3 ). The thickness of ODFs was recorded in the range of $0.11 \mathrm{~mm} \pm 0.0089-0.63 \mathrm{~mm} \pm 0.0549$. These findings were in accordance with Nair et al. ${ }^{28}$ where the thickness range of the typical film must be within the range of $50 \mu \mathrm{m}-1000 \mu \mathrm{m}$. The optimum and homogenous thickness of the film is requisite for its uniform drug distribution, which ultimately has a profound effect on its content uniformity. ${ }_{4} 1,42$ Uniform drying of ODF is a crucial stage in providing the uniform thickness of the ODF batch. The recorded thickness values were almost uniform in all trials suggesting the homogenous distribution of all ingredients in the ODF. In addition, findings also highlighted the validity of uniform drying in a hot air oven at $45^{\circ} \mathrm{C}$. The ODF with higher thickness values contributes toward diminished pliability and consequently low values in folding fortitude evaluation. ${ }^{43}$

\section{Folding fortitude}

Folding fortitude was observed by rotating the ODF at a single plane of $180^{\circ}$ until it broke. A plasticizer is supposed to impart major pliability properties along with main polymers. In this context, plasticizer plays its role by entrapping itself into the polymer matrix and consequently rupturing and weakening the polymer-polymer linkages and augmenting the motility of polymer strands. ${ }^{44}$ The folding fortitude of all retrieved ODF trial formulations was within the scale of $81.66 \pm 7.63$ $372.33 \pm 1.57$ (Table 3). It was deduced that ODF with a relatively high pullulan content is more pliable and records higher folding fortitude value. In contrast, the ODF with relatively higher HPMC E15 tended to show diminished flexibility and exhibited lowered folding endurance. This deduction was supported by analyzing the recorded folding endurance values of TF5, TF13, TF14, and TF15. All mentioned trial formulations were formulated with relatively higher HPMC E15 than pullulan, which imparted the diminished pliability to ODFs and consequently poor folding endurance. This finding corroborated with ElMeshad and $\mathrm{El}$ Hagrasy ${ }^{45}$, who found that mosapride ODFs formed with HPMC are stiff and lack pliability.

The influence of plasticizer concentration was also observed in the study of clobazam ODFs formation, where the increase in plasticizer concentration imparts enhanced pliability to ODF.46 There is no authentic, official pharmacopeial value range for folding endurance; hence the ODF with more than 250 folding fortitude values were regarded as ODF with good folding fortitude attribute. ${ }^{31}$

\section{Content uniformity}

Drug content homogeneity was examined to ascertain the homogenous and precise distribution of fluoxetine in all successfully retrieved ODF trial batches. Three ODFs out of each trial formulation batch were evaluated using a UV spectrophotometer. Drug content must be within $85-115 \%$ to be

Table 3. Weight variation, thickness, folding fortitude, content uniformity, and disintegration time of trial formulations

\begin{tabular}{|c|c|c|c|c|c|c|}
\hline Sr. no. & Trial no. & $\begin{array}{l}\text { Weight variation } \\
(\mathrm{mg}) \pm \text { standard } \\
\text { deviation }(n=5)\end{array}$ & $\begin{array}{l}\text { Thickness mean } \\
(m m) \pm \text { standard } \\
\text { deviation }(n=5)\end{array}$ & $\begin{array}{l}\text { Folding fortitude } \\
\text { mean } \pm \text { standard } \\
\text { deviation }(n=3)\end{array}$ & $\begin{array}{l}\text { Drug content uniformity (\%) } \\
\text { mean } \pm \text { standard deviation } \\
(n=3)\end{array}$ & $\begin{array}{l}\text { Mean disintegration } \\
\text { time }(\sec ) \pm \text { standard } \\
\text { deviation }(n=3)\end{array}$ \\
\hline 1 & TF4 & $82.55 \pm 0.17$ & $0.16 \pm 0.01$ & $276.33 \pm 1.52$ & $80.09 \pm 0.07$ & $20.33 \pm 0.57$ \\
\hline 2 & TF5 & $72.67 \pm 0.12$ & $0.11 \pm 0.01$ & $140.33 \pm 4.16$ & $81.33 \pm 5.04$ & $19.66 \pm 0.53$ \\
\hline 3 & TF6 & $76.68 \pm 0.13$ & $0.14 \pm 0.00$ & $232.66 \pm 3.05$ & $113.58 \pm 0.45$ & $26.66 \pm 1.15$ \\
\hline 4 & TF7 & $83.66 \pm 0.51$ & $0.12 \pm 0.01$ & $372.33 \pm 1.57$ & $98.23 \pm 0.10$ & $10.66 \pm 1.15$ \\
\hline 5 & TF8 & $88.84 \pm 0.07$ & $0.21 \pm 0.02$ & $294.66 \pm 1.63$ & $73.28 \pm 0.15$ & $39 \pm 2$ \\
\hline 6 & TF10 & $83.97 \pm 0.05$ & $0.17 \pm 0.01$ & $287.33 \pm 2.30$ & $90.73 \pm 0.62$ & $20.33 \pm 0.57$ \\
\hline 7 & TF11 & $88.27 \pm 0.12$ & $0.13 \pm 0.00$ & $310.33 \pm 1.57$ & $96.68 \pm 0.43$ & $22 \pm 1$ \\
\hline 8 & TF12 & $92.85 \pm 0.13$ & $0.27 \pm 0.07$ & $320.33 \pm 0.57$ & $82.47 \pm 0.22$ & $41.33 \pm 0.57$ \\
\hline 9 & TF13 & $82.23 \pm 0.18$ & $0.20 \pm 0.01$ & $180.33 \pm 1.52$ & $106.85 \pm 2.28$ & $14 \pm 2$ \\
\hline 10 & TF14 & $88.39 \pm 0.85$ & $0.22 \pm 0.01$ & $201.66 \pm 2.08$ & $118.82 \pm 0.57$ & $30.33 \pm 1.52$ \\
\hline 11 & TF15 & $95.05 \pm 1.25$ & $0.52 \pm 0.03$ & $81.66 \pm 7.63$ & $89.41 \pm 0.25$ & $44.66 \pm 2.08$ \\
\hline 12 & TF16 & $102.42 \pm 1.41$ & $0.63 \pm 0.05$ & $161.66 \pm 10.40$ & $84.39 \pm 0.06$ & $48.33 \pm 2.57$ \\
\hline
\end{tabular}


regarded as a successful batch. ${ }^{20}$ Drug load of $10 \mathrm{mg}$ per ODF of $4 \mathrm{~cm}^{2}$, which corresponds to $2.5 \mathrm{mg} / \mathrm{cm}^{2}$, was targeted to be achieved in all ODF trial batches, whereas the ranges of drug content in fluoxetine ODFs were found to be from $73.28 \% \pm 0.15$ to $118.82 \% \pm 0.57$ (Table 3 ).

\section{Disintegration time}

As European pharmacopeia publishes that ODF must disintegrate as placed in a buccal cavity. However, it does not declare any authentic method and maximal acceptable time for disintegration. Centre of drug evaluation and research states that the disintegration time range should be within the limits of 0-30 sec, so the same criterion was selected for ODF.47,48

PVP was employed as the super-disintegrant in a concentration of $160 \mathrm{mg}$ per ODF batch. The PVP performs rapid disintegration by absorbing water through capillary action and expands, ultimately increasing hydrostatic pressure, which is required to disintegrate ODF readily. ${ }^{43}$ Notably, the disintegration time ascended with the aggravation of polymer content in the ODF trials. Furthermore, the constant concentration of superdisintegrant in all ODFs was sparse to induce the disintegration in ODF of such high polymer content. Therefore, it can be assumed that the concentration of super-disintegrant must be commensurate with polymer content in ODF, and its higher concentration will lead to faster disintegration. Moreover, high polymer content could also be the cause to seal the capillary pores and ultimately block the influx of liquid into ODF, resulting in delayed disintegration time. ${ }^{49}$

ODF trial batches recorded the disintegration time equal to or less than $30 \mathrm{sec}$ were regarded as the successful ODF in terms of disintegration time characterization (Table 3). TF7 manifested itself with an exceptional and phenomenal disintegration time of just $10.66 \mathrm{sec}$. After keen analysis of disintegration time correlated to polymer percentage, it was inferred that ODFs formulated with $45 \%$ of polymer content revealed themselves with exceptionally short disintegration time up to $19 \mathrm{sec}$. The recorded data showed that PVP proved itself as a competent super-disintegrant for the ODF formulation, although its efficacy is contingent on incorporating polymer concentration.

\section{In vitro dissolution studies}

No official drug release method of ODF is prescribed in pharmacopeias to be referred to for in vitro drug release characterization. For drug release, large volumes of media were used, whereas it did not conform to the limited saliva volume capacity of the buccal cavity. ${ }^{23}$

Additionally, the media used is not a bio-relevant medium and does not conform to physiological conditions of the buccal cavity. Due to the unavailability of artificial saliva in the research lab, phosphate buffer of $\mathrm{pH} 6.8$ was used in dissolution apparatus type II, and absorbance was recorded at $263 \mathrm{~nm}$. The dissolution apparatus used only permits the sampling to be taken at the minimum intervals of $30 \mathrm{sec}$, and it is not possible to withdraw the samples less than $30 \mathrm{sec}$. All the ODF batches exhibited a gradual increase in the percentage of drug release over the 11min assay runtime. The percentage of drug release of ODF also varied along the consecutive $11 \mathrm{~min}$ of assay runtime (Table 4). It was due to various concentration combinations of polymers, pullulan, and HPMC. The fastest drug dissolution was observed in TF7, which almost completely released (99.37\%) of fluoxetine within $3 \mathrm{~min}$ (Figure 1). It was deduced from the recorded data that ODF with lower polymer content tended to exhibit fast drug release. ODF formulated with total polymer content between $35 \%$ and $45 \%$ faster releasing the fluoxetine than other ODF batches, reaching their maximum drug release in 5 min (Figure 1a).

ODFs formulated with a higher polymer concentration (50$60 \%$ ) combination of pullulan and HPMC E15 showed a slow drug release pattern (Figure 1b). Similar outcomes were observed in the levothyroxine ODF formulation, where films formed with a higher percentage of polymer content tended to slow down the release of levothyroxine. ${ }^{26}$ It was concluded that

Table 4. Cumulative percentage of drug release of fluoxetine orodispersible film batches (in vitro dissolution studies)

\begin{tabular}{llllllllllll} 
Time (min) & 0 & 0.5 & 1 & 1.5 & 2 & 2.5 & 3 & 5 & 7 & 9 & 11 \\
\hline TF4 & 0 & 15.65 & 26.98 & 39.31 & 55.51 & 66.30 & 76.01 & 80.14 & 80.71 & - \\
\hline TF5 & 0 & 13.71 & 30.15 & 42.15 & 50.01 & 59.81 & 72.15 & 83.91 & 84.42 & - \\
\hline TF6 & 0 & 7.30 & 18.95 & 32.33 & 45.12 & 56.13 & 68.31 & 86.15 & 103.21 & - & - \\
\hline TF7 & 0 & 23.13 & 41.15 & 66.15 & 82.15 & 96.75 & 99.37 & - & - & - \\
\hline TF8 & 0 & 5.15 & 12.31 & 22.15 & 38.01 & 57.60 & 68.91 & 80.15 & 81.12 & - \\
\hline TF10 & 0 & 16.71 & 29.15 & 41.65 & 59.36 & 73.12 & 80.12 & 98.15 & - & - & - \\
\hline TF11 & 0 & 9.16 & 18.15 & 25.79 & 38.29 & 52.76 & 65.90 & 83.15 & 97.61 & - \\
\hline TF12 & 0 & 4.9 & 9.53 & 18.15 & 26.15 & 39.56 & 50.25 & 67.53 & 85.93 & 98.47 & - \\
\hline TF13 & 0 & 19.45 & 37.26 & 54.57 & 71.77 & 86.89 & 98.35 & 102.4 & - & - \\
\hline TF14 & 0 & 12.17 & 20.65 & 30.45 & 43.25 & 57.48 & 67.38 & 84.74 & 98.30 & 113.15 & - \\
\hline TF15 & 0 & 7.80 & 14.16 & 22.15 & 33.67 & 49.56 & 63.21 & 75.5 & 84.56 & 87.75 & 87.81 \\
\hline TF16 & 0 & 5.90 & 9.40 & 12.45 & 18.45 & 22.56 & 32.76 & 49.65 & 62.43 & 78.57 & 89.35 \\
\hline
\end{tabular}


CPDR slowed down in ODFs with higher polymer content. This was presumably due to higher polymer quantity, which could cause the generation of robust matrix layer by close and indepth contact among the swollen matrix's molecular structures of, which possibly participated in the slow drug release phenomenon. ${ }^{42}$

\section{Analysis and selection of optimized formulation}

The most optimized formulation was selected by evaluating the characterization data of all ODF batches. The selection was based on the criteria of ODF with instant detachability/ peel ability from petri dish mold, rapid maximum drug release in a minimum period, the briefest disintegration time, acceptable folding endurance, and content uniformity. The results showed that TF7 possessed the most desired properties. TF7 was then reformulated with the same concentration and procedure and further evaluated for mechanical properties such as SEM, XRD, and TGA.

\section{Tensile strength, percent elongation, and Young's modulus}

The main objective of the tensile test was to evaluate the fortitude and plasticity of TF7. The TF7 of $30 \mathrm{~mm} \times 16 \mathrm{~mm}$ was tested in UTM by mounting it between two tensioning clamps, and the motile clamp was set at the speed of $1.0 \mathrm{~mm} / \mathrm{min}$. Then load at break was observed, which ruptured the ODF at 0.1200 $\mathrm{N}$. It was noted that the sample was ruptured at the middle of ODF instead of ODF at clamps.
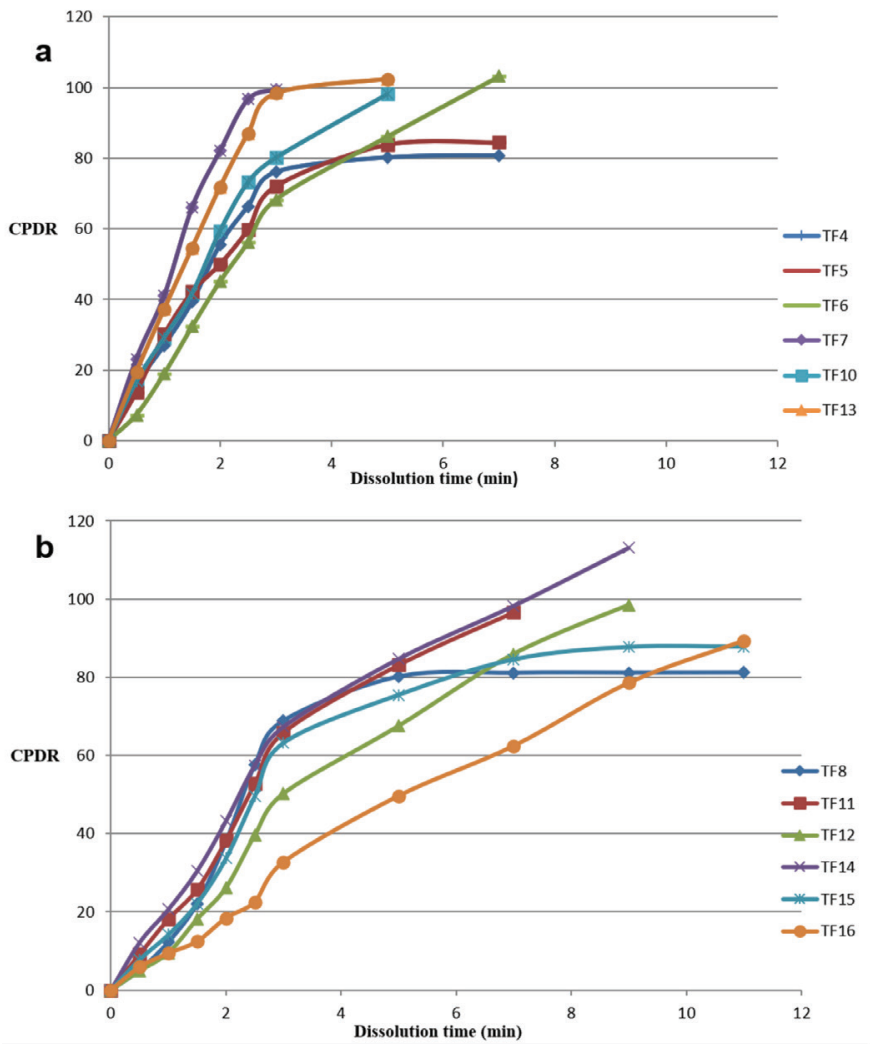

Figure 1. Dissolution profile of all trial ODFs: (a) Dissolution profile of ODFs with $35-45 \%$ content of polymer and (b) dissolution profile of ODFs with $50-60 \%$ content of polymer

ODFs: Orodispersible films
It is essential for the finished product to meet the requisite parameter criteria for its required competent functioning. Hence, to achieve this aspect, critical quality attributes (CQA) are supposed to be specified. ${ }^{50}$ Classical ODF must be physically robust and pliable. These traits can be interpreted as classical ODF must possess high tensile strength and high percent elongation at rupture and low value of Young's modulus. According to CQA of mechanical properties of ODF, corresponding values should be as tensile strength $>2 \mathrm{~N} /$ $\mathrm{mm}^{2}$, \% elongation $>10 \%$, Young's modulus $\left\langle 550 \mathrm{~N} / \mathrm{mm}^{2}{ }^{21}\right.$ The mechanical properties of TF7: Tensile strength was $5.76 \mathrm{~N} / \mathrm{mm}^{2}$, $\%$ elongation was 38.85\%, and Young's modulus was $280.37 \mathrm{~N} /$ $\mathrm{mm}^{2}$. The results indicated the robustness of the TF7 structure (see detailed results in Table 5).

Therefore, TF7 is robust, flexible, and tough. The concentration of incorporated plasticizer (PG) has positive effects on tensile strength, and \% elongation could be due to bonds formation between PG (plasticizer) and polymer (pullulan \& HPMC E15), thereby imparting adequate flexibility and fortitude to ODF to endure and resist the rupture. However, it was found that plasticizer concentration has a negative effect on disintegration time. ${ }^{26}$ It is also to be considered that much higher elongation is not desirable because it could generate the problem of elongation at edges while cutting the ODF batches, which could yield inhomogeneous ODFs, and diversify drug load. Therefore,

Table 5. Universal Testing Machine test results of optimized formulation of TF7

\begin{tabular}{ll} 
Area $\left(\mathrm{mm}^{2}\right)$ & 16.000 \\
\hline Diameter (mm) & 16.000 \\
\hline Elongation @ break (mm) & 11.657 \\
\hline Elongation @ peak (mm) & 0.5470 \\
\hline Elongation @ yield (mm) & 0.4910 \\
\hline Energy @ break (N.m) & 0.0016 \\
\hline Energy @ peak (N.m) & 0.0024 \\
\hline Energy @ yield (N.m) & 0.0020 \\
\hline Load @ break (N) & 0.1200 \\
\hline Load @ peak (N) & 7.1700 \\
\hline Load @ yield (N) & 7.0100 \\
\hline Plastic strain @ break (\%) & 38.877 \\
\hline Strain @ break (\%) & 38.857 \\
\hline Strain @ peak (\%) & 1.8233 \\
\hline Strain @ yield (\%) & 1.6367 \\
\hline Stress @ break (N/mm²) & 0.0577 \\
\hline Stress @ peak (N/mm²) & 3.4471 \\
\hline Stress @ yield (N/mm²) & 3.3702 \\
\hline Young's modulus (N/mm²) & 280.37 \\
\hline
\end{tabular}


optimal incorporation of appropriate plasticizer concentration holds key importance in the formation of classical ODF with adequate physical attributes. ${ }^{52}$

\section{$X$-ray diffractometry}

The XRD patterns investigation of pure fluoxetine powder showed clear and sharp peaks, implying that it is pure and crystalline. Peak signals were distinctively manifested at two theta $(\theta): 20.30^{\circ}, 21.94^{\circ}, 23.79^{\circ}, 27.94^{\circ}$, which substantiated the high crystallinity of fluoxetine. The findings of Childs et al. ${ }^{53}$ also corroborated the XRD pattern of the current investigation. XRD patterns of placebo formulation (TFO) showed no signal of fluoxetine peak as it was devoid of fluoxetine. TFO gave no distinct peak in its XRD analysis pattern, verified its incorporated excipients' amorphous nature and lack of crystallinity. XRD investigation of TF7 manifested the peak signals of fluoxetine, which substantiated the efficient loading of fluoxetine into the TF7 and indicated the fluoxetine recrystallization phenomena (Figure 2). However, peak signal intensities of TF7 were less pronounced and showed minor aberration compared to peak intensities of pure fluoxetine. Due to the already detected $98.23 \%$ content uniformity of TF7, it can be conclusively affirmed that fluoxetine did not decompose, but rather fluoxetine presumably recrystallized in another refitting.

ODF technology is typically focused on water-soluble drugs, and the ideal case dictates that after solvent evaporation, the drug retains its dissolved form in the ODF matrix and does not crystallize. Whereas during experimentation, it usually differs from the ideal situation. ${ }^{54}$ Fluoxetine is a white powder drug with crystalline form, which exists in multiple polymorph crystalline forms. The results indicated that fluoxetine stays in crystalline form in ODFs, which could exert its multi-faceted effects. On the one hand, this crystallinity refers to the enhanced inherent stability of the drug in a dosage form. On the other hand, a stable crystal form of the drug may display inadequate solubility, dissolution rate, and effects on pharmacokinetics. ${ }^{55}$ Here it is noteworthy that recrystallization of fluoxetine in TF7 can exert its excessive influence on the disintegration properties, and dissolution, which may lead to problematic bioavailability. ${ }^{23}$

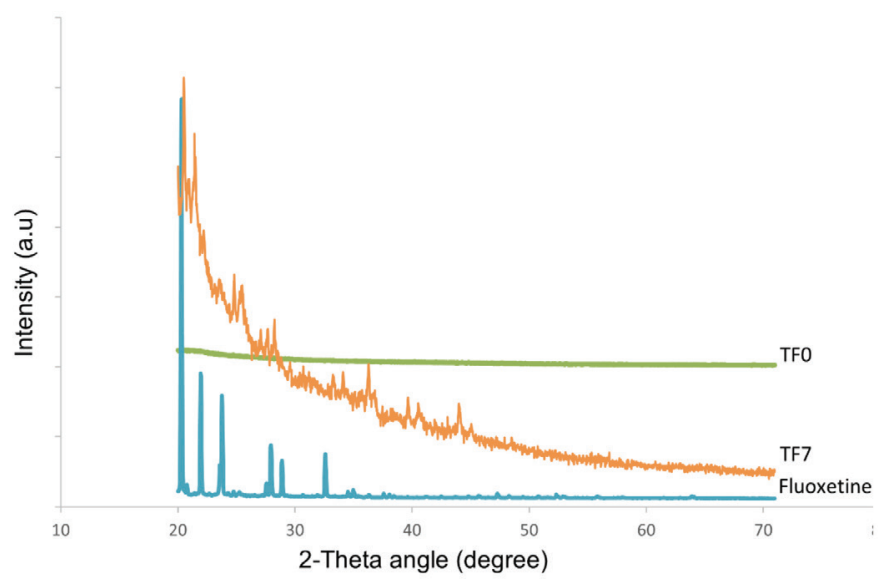

Figure 2. X-ray diffraction patterns of fluoxetine, TF7, and TFO
However, these influences need to be explored further in future studies, especially concerning its in vivo effects.

\section{SEM}

The SEM was performed for the morphological comparison of TF7 with TFO. Naked eye visual evaluation of TF7 and TFO ostensibly reveal not much difference in their surface morphology; both ODFs exhibit relatively smooth surfaces. However, it was observed that the surface structure of TF7 and TFO varied from each other. Both samples showed coarse surfaces on higher resolution images of SEM. TF7 showed drug particles on its surface, but TFO had no crystal-like drug particles presented on it (Figure 3).

It was observed in SEM images that fluoxetine recrystallized and formed a needle-like structure in TF7. In comparison, TFO was devoid of such needle-like crystal structures. The XRD pattern of TF7 can also validate the recrystallization phenomena of fluoxetine in SEM of TF7. Fluoxetine recrystallization could contribute to the coarseness or roughness of the TF7 surface observed under high resolution. Previous studies suggest that the crystalline nature of drugs may severely influence the mechanical characteristics of ODF by imparting more brittleness and less transparency. ${ }^{56}$ However, as per our results, recrystallization of fluoxetine in TF7 could not negatively display its impact on final dosage, presumably owing to excellent polymer selection and plasticizer role.

\section{TGA}

The optimized formulation of TF7 and pure drug fluoxetine were subjected to TGA. It was found that fluoxetine showed initial weight loss at $165^{\circ} \mathrm{C}$ and ensued by frequent weight loss around $208^{\circ} \mathrm{C}$, which elucidated the initiation of fluoxetine decomposition. As the temperature reached $228^{\circ} \mathrm{C}$, an abrupt and massive plummet in the mass of fluoxetine was spotted, which conspicuously correspond to the decomposition of fluoxetine.

The commencement of decline in the mass of TF7 can be observed in the initial stage of heating exposure. This mass decline can be presumably attributed to the evaporation of its entrapped wat er molecules and not the degradation of polymers in ODF. The degradation profile of TF7 is also attributed to

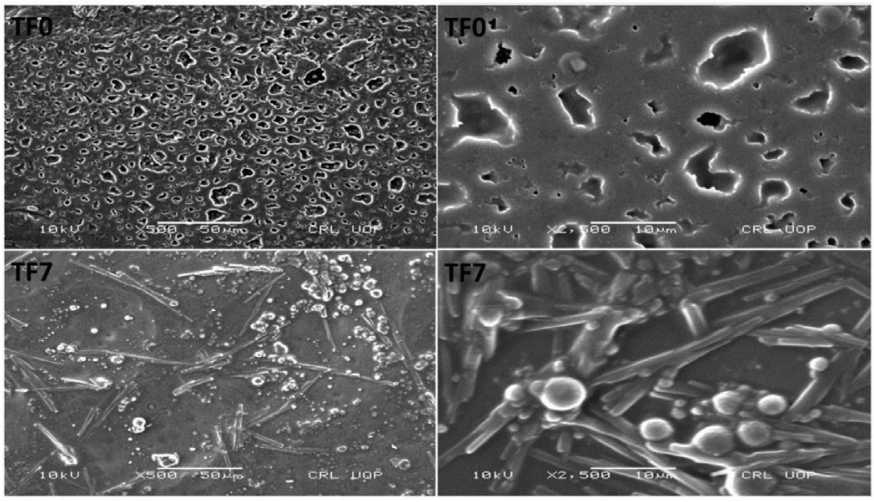

Figure 3. Scanning electron microscopy images of TFO and TF7 


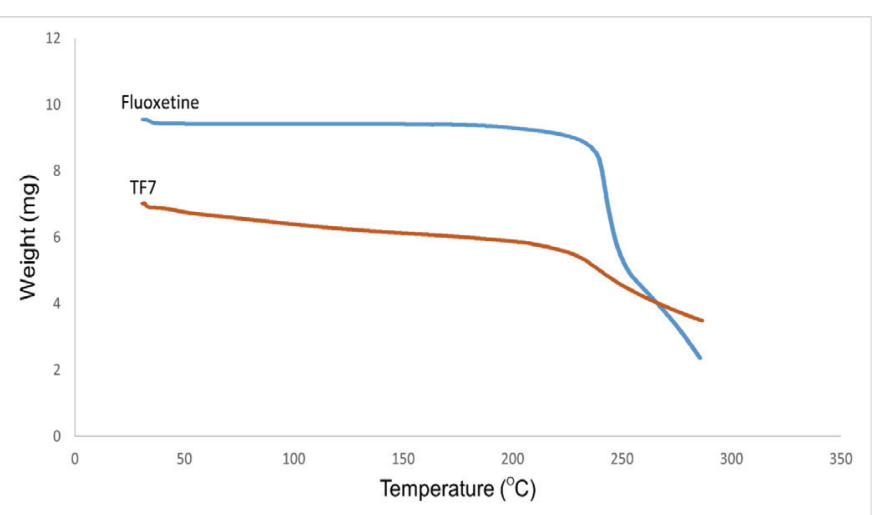

Figure 4. Thermogravimetric analysis curve of fluoxetine and TF7

the incorporated excipients. As ODF are highly susceptible to moisture uptake and regarded as hygroscopic, it is crucial to attribute the initial weight loss up to $100^{\circ} \mathrm{C}$ due to evaporation of water molecules. According to previously reported data, the TGA profile of $P G$ suggested that $P G$ degradation initiated at low temperature. ${ }^{57}$

It can be inferred from the data that TF7 comprised a higher percentage of polymers, and the ability of both polymers to retain water molecules in their matrices cannot be ignored while inspecting the TGA profile of formulation. Initial weight loss can be attributed to drying and water evaporation, followed by PG'searly degradation tendency. In addition, considerable mass decomposition spotted after $220^{\circ} \mathrm{C}$ can certainly be ascribed to fluoxetine decomposition as elucidated in the TGA of fluoxetine (Figure 4).

\section{CONCLUSION}

ODFs fabricated with cumulative percentage content of hydrophilic film-forming polymers (pullulan and HPMC E15) within the range of $35-45 \%$ resulted in shorter disintegration time and faster percentage drug release. PG exerts excellent plasticizing characteristics in formulating ODFs, and it imparted satisfactory tenacity and flexibility to ODFs. Conclusively, as the formulation of fluoxetine ODF was successful and has been thoroughly characterized with unobjectionable results, this dosage form sets a precedent and future prospect for further uptake of its in vivo evaluation by the scientific community and ensuing compliance studies in pediatrics patients of selective mutism and OCD. It is hypothesized that the convenience will persuade pediatric psychiatric patients in the need of fluoxetine of ODF. There is also an imperative necessity of standardized methods and official guidelines for the evaluation techniques of ODF for efficient quality analysis.

Conflict of interest: No conflict of interest was declared by the authors. The authors are solely responsible for the content and writing of this paper.

\section{REFERENCES}

1. Strickley RG, Iwata $Q$, Wu S, Dahl TC. Pediatric drugs-a review of commercially available oral formulations. J Pharm Sci. 2008;97:17311774.

2. van Riet-Nales DA, Schobben AF, Vromans H, Egberts TC, Rademaker CM. Safe and effective pharmacotherapy in infants and preschool children: importance of formulation aspects. Arch Dis Childh. 2016;101:662-669.

3. Senta-Loys Z, Bourgeois S, Pailler-Mattei C, Agusti G, Briançon S, Fessi, H. Formulation of orodispersible films for paediatric therapy: investigation of feasibility and stability for tetrabenazine as drug model. J Pharm Pharmacol. 2017;69:582-592.

4. Dahiya M, Saha S, Shahiwala AF. A review on mouth dissolving films. Curr Drug Deliv. 2009;6:469-476.

5. Zarafshan H, Mohammadi MR, Salmanian M. prevalence of anxiety disorders among children and adolescents in Iran: a systematic review. Iran J Psychiatry. 2015;10:1-7.

6. Wong P. Selective mutism: a review of etiology, comorbidities, and treatment. Psychiatry (Edgmont). 2010;7:23-31.

7. Stein DJ, Craske MA, Friedman MJ, Phillips KA. Anxiety disorders, obsessive-compulsive and related disorders, trauma- and stressorrelated disorders, and dissociative disorders in DSM-5. Am J Psychiatry. 2014;171:611-613.

8. Capozzi F, Manti F, Di Trani M, Romani M, Vigliante M, Sogos C. Children's and parent's psychological profiles in selective mutism and generalized anxiety disorder: a clinical study. Eur Child Adolesc Psychiatry. 2018;27:775-783.

9. Barterian JA, Sanchez JM, Magen J, Siroky AK, Mash BL, Carlson JS. An examination of fluoxetine for the treatment of selective mutism using a nonconcurrent multiple-baseline single-case design across 5 cases. $J$ Psychiatr Pract. 2018;24:2-14.

10. Alaghband-Rad J, Hakimshooshtary M. A randomized controlled clinical trial of citalopram versus fluoxetine in children and adolescents with obsessive-compulsive disorder (OCD). Eur Child Adolesc Psychiatry. 2009;18:131-135.

11. Liebowitz MR, Turner SM, Piacentini J, Beidel DC, Clarvit SR, Davies SO, Graae F, Jaffer M, Lin SH, Sallee FR, Schmidt AB, Simpson HB. Fluoxetine in children and adolescents with OCD: a placebo-controlled trial. J Am Acad Child Adolesc Psychiatry. 2002;41:1431-1438.

12. Strawn JR, Welge JA, Wehry AM, Keeshin B, Rynn MA. Efficacy and tolerability of antidepressants in pediatric anxiety disorders: a systematic review and meta-analysis. Depress Anxiety. 2015;32:149-157.

13. Carlson JS, Mitchell AD, Segool N. The current state of empirical support for the pharmacological treatment of selective mutism. Sch Psychol $Q$. 2008;23:354-372.

14. Sayed S, Horn SR, Murrough JW. Current treatments for anxiety and obsessive-compulsive disorders. Curr Treat Options Psychiatry. 2014:1:248-262.

15. Manassis, K Oerbeck B, Overgaard KR. The use of medication in selective mutism: a systematic review. Eur Child Adolesc Psychiatry. 2016;25:571-578

16. Ercan ES, Kandulu R, Ardic UA. Preschool children with obsessivecompulsive disorder and fluoxetine treatment. Eur Child Adolesc Psychiatry. 2012;21:169-172. 
17. Giasuddin NA, Nahar JS, Morshed NM, Balhara Y, Sobhan MA. Efficacy of combination of fluoxetine and cognitive behavioral therapy and fluoxetine alone for the treatment of obsessive compulsive disorder. Pak J Pharm Sci. 2013;26:95-98.

18. Hansen DL, Tulinius D, Hansen EH. Adolescents' struggles with swallowing tablets: barriers, strategies and learning. Pharm World Sci. 2008;30:65-69.

19. Schiele JT, Quinzler R, Klimm HD, Pruszydlo MG, Haefeli WE. Difficulties swallowing solid oral dosage forms in a general practice population: prevalence, causes, and relationship to dosage forms. Eur J Clin Pharmacol. 2013;69:937-948.

20. Dixit R, Puthli S. Oral strip technology: overview and future potential. J Control Release. 2009;139:94-107.

21. Mahajan A, Chhabra N, Aggarwal G. Formulation and characterization of fast dissolving buccal films: a review. Der Pharm Lett. 2011;3:152-165.

22. Kaur R, Bala R, Malik D. A novel approach in oral fast dissolving drug delivery system-a review. Am J PharmTech Res. 2012;2:88-104.

23. Hoffmann EM, Breitenbach A, Breitkreutz J. Advances in orodispersible films for drug delivery. Expert Opin Drug Deliv. 2011;8:299-316.

24. Saini P, Kumar A, Sharma P, Visht S. 8. fast disintegrating oral films: a recent trend of drug delivery. Int J Drug Dev Res. 2012;7:60-75.

25. Scarpa M, Stegemann S, Hsiao WK, Pichler H, Gaisford S, Bresciani M. Orodispersible films: towards drug delivery in special populations. Int J Pharm. 2017;523:327-335.

26. Zhang H, Han MG, Wang Y, Zhang J, Han ZM, Li SJ. Development of oral fast-disintegrating levothyroxine films for management of hypothyroidism in pediatrics. Trop J Pharm Res. 2015;14:1755-1762.

27. Liew KB, Tan YT, Peh KK. Characterization of oral disintegrating film containing donepezil for Alzheimer disease. AAPS PharmSciTech. 2012;13:134-142.

28. Nair AB, Kumria R, Harsha S, Attimarad M, Al-Dhubiab BE, Alhaider IA. In vitro techniques to evaluate buccal films. J Control Release. 2013;166:1021.

29. Sultana F, Arafat M, Pathan SI. Preparation and evaluation of fast dissolving oral thin film of caffeine. International J Pharm Biol Sci. 2013;3:153-161.

30. El-Setouhy DA, Abd El-Malak NS. Formulation of a novel tianeptine sodium orodispersible film. AAPS PharmSciTech. 2010;11:1018-1025. Erratum in: AAPS PharmSciTech. 2010;11:1499. El-Malak, Nevine Shawky Abd [corrected to Abd El-Malak, Nevine Shawky].

31. Preis M, Woertz C, Kleinebudde P, Breitkreutz J. Oromucosal film preparations: classification and characterization methods. Expert Opin Drug Deliv. 2013;10:1303-1317.

32. Preis $M$, Pein M, Breitkreutz J. Development of a taste-masked orodispersible film containing dimenhydrinate. Pharmaceutics. 2012;4:551-562.

33. Arya A, Chandra A, Sharma V, Pathak K. Fast dissolving oral films: an innovative drug delivery system and dosage form. Int $\mathrm{J}$ Chemtech Res. 2010;2:576-583.

34. Singh $\mathrm{H}$, Kaur $\mathrm{M}$, Verma $\mathrm{H}$. Optimization and evaluation of desloratadine oral strip: an innovation in paediatric medication. ScientificWorldJournal. 2013;2013:395681.
35. Abdelbary A, Bendas ER, Ramadan AA, Mostafa DA. Pharmaceutical and pharmacokinetic evaluation of a novel fast dissolving film formulation of flupentixol dihydrochloride. AAPS PharmSciTech. 2014;15:1603-1610.

36. Juliano C, Cossu M, Pigozzi P, Rassu G, Giunchedi P. Preparation, in vitro characterization and preliminary in vivo evaluation of buccal polymeric films containing chlorhexidine. AAPS PharmSciTech. 2008;9:1153-1158.

37. Pereda M, Ponce A, Marcovich N, Ruseckaite R, Martucci J. Chitosangelatin composites and bi-layer films with potential antimicrobial activity. Food Hydrocolloids 2011;25:1372-1381.

38. Cilurzo F, Cupone IE, Minghetti P, Buratti S, Gennari CG, Montanari L. Diclofenac fast-dissolving film: suppression of bitterness by a tastesensing system. Drug Dev Ind Pharm. 2011;37:252-259.

39. Changdeo JS, Vinod M, Shankar KB, Rajaram CA. Physicochemical characterization and solubility enhancement studies of allopurinol solid dispersions. Braz J Pharm Sci. 2011;47:513-523.

40. Mahesh A, Shastri N, Sadanandam M. Development of taste masked fast disintegrating films of levocetirizine dihydrochloride for oral use. Curr Drug Deliv. 2010;7:21-27.

41. Bala R, Pawar P, Khanna S, Arora S. Orally dissolving strips: a new approach to oral drug delivery system. Int J Pharm Investig. 2013;3:6776.

42. Padamwar A, Phasate PP. Formulation and evaluation of fast dissolving oral film of bisoprolol fumarate. Int J Pharm Sci Res. 2015;6:135-142.

43. Heer D, Aggarwal G, Kumar SH. Development of fast dissolving oral films and tablets of cinnarizine: effect of superdisintegrants. Int J Pharm Pharm Sci. 2014;6:186-191.

44. Entwistle C, Rowe R. Plasticization of cellulose ethers used in the film coating of tablets. J Pharm Pharmacol. 1979;31:269-272.

45. ElMeshad AN, El Hagrasy AS. Characterization and optimization of orodispersible mosapride film formulations. AAPS PharmSciTech. 2011;12:1384-1392.

46. Bala R, Khanna S, Pawar P. Design optimization and in vitro-in vivo evaluation of orally dissolving strips of clobazam. J Drug Deliv. 2014;2014:1-15

47. Brniak W, Maślak E, Jachowicz R. Orodispersible films and tablets with prednisolone microparticles. Eur J Pharm Sci. 2015;75:81-90.

48. Patel AR, Prajapati DS, Raval JA. Fast dissolving films (FDFs) as a newer venture in fast dissolving dosage forms. Int J Drug Dev Res. 2010;2:232246.

49. Auda SH, El-Badry M, Ibrahim MA. Design, formulation and characterization of fast dissolving film containing dextrometorphan. Dig. J Nanomater Bios. 2014;9:133-141.

50. Rathore AS, Winkle H. Quality by design for biopharmaceuticals. Nat Biotechnol. 2009;27:26-34.

51. Visser JC, Dohmen WM, Hinrichs WL, Breitkreutz J, Frijlink HW, Woerdenbag HJ. Quality by design approach for optimizing the formulation and physical properties of extemporaneously prepared orodispersible films. Int J Pharm. 2015;485:70-76.

52. Preis M, Knop K, Breitkreutz J. Mechanical strength test for orodispersible and buccal films. Int J Pharm. 2014;461:22-29. 
53. Childs SL, Chyall LJ, Dunlap JT, Smolenskaya VN, Stahly BC, Stahly GP. Crystal engineering approach to forming cocrystals of amine hydrochlorides with organic acids. Molecular complexes of fluoxetine hydrochloride with benzoic, succinic, and fumaric acids. J Am Chem Soc. 2004;126:13335-13342.

54. Centkowska K, Ławrecka E, Sznitowska M. Technology of orodispersible polymer films with micronized loratadine-influence of different drug loadings on film properties. Pharmaceutics. 2020;12:250.

55. Yadav AV, Shete AS, Dabke AP, Kulkarni PV, Sakhare SS. Co-crystals: a novel approach to modify physicochemical properties of active pharmaceutical ingredients. Indian J Pharm Sci. 2009;71:359-370.
56. Gupta MS, Kumar TP. Characterization of Orodispersible Films: An Overview of Methods and Introduction to a New Disintegration Test Apparatus Using LDR - LED Sensors. J Pharm Sci. 2020;109:2925-2942.

57. Malecha K, Maeder T, Jacq C, Ryser P. Structuration of the low temperature co-fired ceramics (LTCC) using novel sacrificial graphite paste with PVA-propylene glycol-glycerol-water vehicle. Microelectron Reliab. 2011;51:805-811. 